\title{
The Small, Remote, or Odd College: Making the Most Out of Your New Teaching Position
}

\author{
Mary Durfee, Michigan Technological University
}

O kay. Princeton did not thrill to your vita. In fact, none of the big schools seem interested in hiring you. Fortunately, you have an offer from a school you had never heard of before you read their ad in the Personnel Service Newslet-

ter. Heck, the last time you had even thought about the state the school is in was for a fifth grade geography quiz. Should you take the offer or join your uncle's insurance firm? Take the offer. Go. Just be certain you stay active when you get there.

No matter how small, remote, or odd your college, you will have ample opportunity to stay active in political science. You will have to work at it a bit more than others, but it can be done. Indeed, you may be able to develop niches for yourself not readily available to colleagues in high-prestige, high-visibility universities. This article offers ideas for making the most of your new position. The ideas come from what I have learned from others as well as from my own experiences at my remote (five hours from the nearest interstate, eight hours from the nearest research library) and odd (it's devoted to engineering and the sciences) university.

\section{You're Part of a Strategy of Excellence-But Does the College Understand How to Promote Excellence?}

As I have heard many times from my senior colleagues, the best time to build a department is when it's a

\footnotetext{
Mary Durfee is an associate professor in the social sciences department at Michigan Technological University. She is coauthor with James N. Rosenau of Thinking Theory Thoroughly (Westview, 1995), and has published in Publius, Millenium, and College Teaching. She is currently completing an edited book on environmental indicators and public policy and another on the Great Lakes of North America.
}

buyers market. So, the fact that you have a job offer means you are a part of that institution's strategy for excellence. Some institutions, however, want to improve themselves but have no conception of what's required to help new faculty achieve excellence. Thus, if you have a choice between schools, look for the following factors that will help you make the most of your own talents.

- Travel funds: You absolutely have to go to at least one major conference a year. If you have no money, or have to compete with everyone in the college for a handful of dollars, you will tend to avoid this crucial chance to interact with others in your field. Ideally, you want funds you can use for any research or professional activity. Many larger schools do not give much travel money (they expect you to get grants), but the smart "let's build excellence" schools provide such funds.

- An expectation of publications: You really don't want to go to a place where a book review is all it takes for tenure (assuming any such places still exist). I found it really helped me develop my own capacities as a scholar to have strong pressure to publish. Otherwise, I would have let teaching and committee service simply swallow up my energies. My teaching is stronger as a consequence, too. Students like a professor to bring personal experiences with research and writing into the classroom.

- Senior colleagues who publish: It is difficult to generate the internal enthusiasm to go to the office day after day for years on end if you never see another soul after hours. Look for a department (and an institution) where many senior people are at least as busy as the untenured folks. Lively colleagues, no matter how small the school, make for a climate conducive to excellence.

- Senior colleagues who will engage in "teacher talk" without turning it into a daily critique of your progress: Preparing for class will utterly consume your first year on the job; later it will provide enormous satisfaction. It helps if others like to talk about their successes and failures as teachers. You might even get some mentoring. Becoming a teacher, however, is an on-going process of learning what choices work for you in a classroom. Thus, you don't need senior people scrutinizing your every move.

- Decent access to the Internet and regular computer upgrades: Perhaps this is no longer a problem anywhere, but it is hard to prepare lectures, class projects, or articles on a clunker computer. Access to the Internet is a major boon to your remaining "connected" to the rest of the world.

- Few adjuncts: A healthy academic community requires mutual, long-term commitment and trust between faculty and administration. The commitment to hire people on tenure lines (and then to tenure them if all goes well) is part of any plan for achieving institutional excellence. This is especially true if the college has a tradition of shared governance, because that entails considerable faculty committee work.

- Support programs: My school grants Ph.D.s in engineering, the sciences, technical writing, and forestry; therefore, I benefit from programs that might not be available in a small, 
four-year college. Nevertheless, you may find similar programs in small schools. My university has a faculty development grant program, as well as one for purchasing new research equipment. There is a special "first year" teacher mentoring and seminar system. We have annual awards for distinguished teaching and for research excellence. Finally, my university encourages us to get fellowships and will grant leaves to tenuretrack faculty if a fellowship application proves successful. We are also allowed to buy out time from teaching if we get research grants. A number of colleges now provide midtenure-stream sabbaticals; that would be a major benefit for any new faculty member.

- Competent administration and minimal bureaucracy: The chair of your department has the most effect on your daily life, but a good team of higher administrators do matter. I've been struck by how many of my colleagues elsewhere get stymied by poor administrators or counterproductive bureaucracy. The soundness of my university on both these counts has grown in importance to me over the years.

\section{Typical Problems for Faculty of the Small, Remote, and Odd College and What to Do About Them}

Once you have accepted the offer, you may encounter problems in balancing research, teaching, and other professional activities. Here are some typical complaints and what you might do about them. Whatever you do, listen to your colleagues about tenure expectations, try to be collegial, and attempt to find a balance that fits your own personality.

\section{There is Too Much Teaching, So I Have No Time for Research}

If you ask some of the most senior people in our field about their teaching loads when they started out in the 1950s, you'll discover that you have nothing to complain about in comparison. Do remember, too, that universities of all stripes are under strong pressure to teach undergrads well. Small liberal arts colleges define themselves through outstanding teaching. Teaching takes every bit as much time to do well as writing and research.

Nevertheless, teaching does not take all one's time. Teaching provides a strong sense of satisfaction for "work accomplished," and it is easy to bask in the feeling of this accomplishment. If you carry that too far, however, then you may end up doing none of the other work of a scholar. Distinguish between the actual and the psychological. Does teaching really take all your time? What are you doing with your time?

In my experience, once a course is developed reasonably well, about 20-25 hours a week is all I need to teach my annual 2-2-2 load of six different preparations. I estimate my teaching time by using the following rule of thumb: hours in class + five hours per week on updating and improving lectures + one hour per student per term for office hours, email conversations, and grading (I do my own grading and do not use computerized options). You also have to set aside 3-5 hours each week for assorted committee meetings. Course planning during the year periodically reduces the time available for writing. Writing a syllabus, even for a well-established class, takes me hours. A syllabus for a brand new class can take weeks. At the risk of repeating myself, what all this means for new teachers is this: Do not plan on getting much writing done your first year. You will, in effect, be writing a few hundred really bad term papers (your initial lectures or class projects).

Given those uncertainties, I usually have between 15-20 hours a week to devote to writing, assuming a 40 hour week. This, along with summers, is enough time to produce a small set of publications or papers. Faculty are not, however, on a timeclock. A serious effort to participate in the discipline requires considerably more time on your part. Plan on spending an average of between 50 and 60 hours a week at your work. If you think your colleagues on tenure-track lines in the big schools have a 9-5 job, you are quite mistaken.

You can lighten the load on yourself through thoughtful balancing of teaching and research. Even in the face of heavy teaching loads and other demands on your time, you can make progress on writing. The trick

is to build on what you do in the classroom. What can you research that will help your lectures as well as your prospects for publication? Also, remember one of the virtues of "excessive" teaching: You get more exposure to the discipline of political science (and sometimes also to history, economics, and sociology). Write an article that takes an idea from one branch of political science and applies it to a problem in another subfield of the discipline. Write about teaching and send the essay to College Teaching or to PS. Design and teach a senior-level course where the students do some of the digging. Then, encourage them to publish their findings in undergraduate journals and newspapers. Meanwhile treat the class project as a chance to write a conference paper or an article.

\section{The Library is No Good}

Yes, well. ... Even good libraries are going downhill these days. Odd schools can be the most troublesome on this count. I can have the best available resources, as long as the subjects I study are things like high- 
strength concrete or the latest advances in thermoplastics. These do not come up too frequently in my work, however. So, I now try to get near a major library at both the beginning and the end of a project. If you are merely an hour or two from a major library, make periodic trips to do research there. If you are far away from libraries, then use any visits to the "real" world as a chance to flip through journals; rely on the kindness of friends to put you up for a few days of work. Visiting major libraries may not always work, because new books get checked out quickly at the research libraries, and recent journals go even quicker. Still, the selection is certain to be better than in my school's library. Along with these visits, use other means of staying up to date. $A B C$ Political Science collects the tables of contents of hundreds of journals and, increasingly, journals' web sites provide tables of contents and full articles. Look at book catalogs religiously. Use interlibrary loan heavily. If it costs to use this service at your school, then try to arrange extra funding to cover your work prior to joining the faculty.

The real effect of a poor library lies in the additional time you have to set aside to finish a project. I assume that whatever would take less than a week for a person at Harvard to accomplish will take me at least three weeks to do. For example, interlibrary loan generally cannot get newly published books until 6 months after publication. Lack of journals poses a lesser problem. The only time I have found the journals problem to be a serious, work-stopping issue was in a case when a publisher wanted more citations on a very short turnaround time. I was unable to handle this, so my writing partner had to do more than his share. Fortunately, this does not happen often.

The library problem also suggests an important research strategy: Do not write articles requiring extensive library research. Instead, go out into the world and do empirical work. In my limited experience, work based on field interviews with actual people is in demand. There are lots of interesting problems right inside your community, if you will just look. Even those who emphasize comparative or IR can forge links between local and global concerns.

\section{There's No One to Talk With}

This complaint puzzles me when I hear it. There are so many people to talk with that it is hard to know

where to begin-or stop. First, do talk to colleagues, even if they are not in your field (I'm the sole political scientist at Tech, so I have no choice). You may find historians, engineers, sociologists, biologists, and anthropologists more interesting than you thought. The smaller, odder, or remoter the school, the more necessary you will find it to open communications with colleagues in other disciplines. Seek out people who seem intellectually alive. Excellence is excellence, and you'll have no trouble recognizing it. I've discovered wonderful colleagues through service on committees, participation on multidisciplinary grant projects, or just by emailing a problem/question to other departments and asking for help. Second, use the Internet. Join some discussion lists, if only to lurk. Organize panels and projects via this medium. Write to your friends to talk over ideas and share drafts of papers. Third, go to conferences and try to talk to the people who wrote papers that interested you. Don't forget to talk to graduate students. In other words, resist the temptation to spend all your conference time talking to grad school pals. Fourth, find people to write with in and outside your institution. I have written with a departmental colleague, with others in my university, and with a senior person in my field. These collaborations cum friendships are among the joys of my life.

Try using a variety of strategies together. I have been putting together an edited volume on environmental indicators and public policy. The evolution of this project illustrates the many ways one can stay active in research and writing. The project began when I found some historical documents on water quality in the Great Lakes. The documents were based on bacteriology and on engineering, but had a strong international organization twist to them. I tracked down a microbiologist to explain the science to me, and we soon resolved to write a paper together. A note announcing the biennial meeting of the American Society for Environmental History suggested a good venue for our crazy "Bacteriology and Diplomacy in the Great Lakes: 1912-1929" project. I set up a panel on indicators and public policy for the meeting via the Internet. This led to the book concept and, as it turned out, one of the conference organizers also happened to be a series editor for books on technology and the environment. He encouraged me to make a go of the book.

Our original paper is one chapter. I convinced a colleague in forestry to provide one on forest monitoring work in parts of the former Soviet Union. A departmental colleague wrote one about indicators for the public and those best suited for experts. Another chapter, about changing indicators for a tuna fishery, came from a person I met at a university where I was giving a talk. The rest of the papers, ranging from water and air quality issues around the globe to the tension between experts and First Nations peoples in the Canadian arctic, came in response to my Internet call for contributors. Material from the project went into my teaching, generated a 
possible new line of research, fed into a public service activity I do, and added interesting people from the physical sciences, engineering, and political science to my life.

\section{Get Involved}

Staying involved makes sense strategically, but you'll be happier if you do this for other reasons, like socializing with others and staying intellectually alive. Do, within reason, participate in the committees of your professional organizations as well as your institution. Serve on a community board or volunteer group. Give talks once in a while; your college news bureau can help you find initial opportunities. Announce (and give) a talk in your department or college. When journals ask for book reviewers, volunteer. If NSF, publishers, or journals ask you to be a reviewer, accept. Edit a newsletter. Advise a student organization. You'll get to know some students better and probably meet other faculty advisors in your area. Some faculty take students on study abroad programs. Participate in the
AP Advanced Placement exam "reading." It pays, you get out of town, and most important of all, you'll get to spend time with lots of political scientists and AP high school teachers. Participating in the many facets of academic life has made attending conferences more fun and added a dimension of liveliness that would otherwise have been missing from my life.

\section{Use Your Institution to Find a Niche}

If your school is "odd," then you have an opportunity to link political science and policy issues to the main concerns of your institution. Just as I have slowly been learning more about the political (and nonpolitical) aspects of engineering and the sciences, those at music or agricultural schools can work to create intellectual and institutional links between political science and those subjects. Interdisciplinarity can be a virtue. Pragmatically speaking, it is now a common requirement in RFPs. More idealistically, society needs better bridges between expert fields.
Those in very small schools might also do well to devise interdisciplinary courses. Maintain your core disciplinary strengths, but try some problem solving with others. If your school is remote, there will be plenty of opportunities for community and regional development work. Last, you can take advantage of pedagogical innovations at your college by participating in teaching conferences or sessions organized by regional and national accreditation associations. These settings allow you to emphasize your professional teaching life over that of your research life.

Don't take that job in the insurance firm. Take your chances with that "no name" school that is small or remote or odd, or all three. Don't worry about it any further. You may have to plan more carefully to make the most of your situation than will others with more expansive resources, but you will find it worth the effort. No matter what kind of college you teach in, few other means of keeping body and soul together can match the richness of academic life. 